\title{
A Review on Sampling Techniques and Analytical Methods for Microbiota of Cultural Properties and Historical Architecture
}

\author{
Xinghua Ding ${ }^{1} \mathbb{D}$, Wensheng Lan ${ }^{2} \mathbb{D}$ and Ji-Dong Gu ${ }^{1, *,+}$ \\ 1 Laboratory of Environmental Microbiology and Toxicology, School of Biological Sciences, \\ The University of Hong Kong, Pokfulam Road, Hong Kong, China; u3005522@connect.hku.hk \\ 2 Shenzhen R\&D Key Laboratory of Alien Pest Detection Technology, The Shenzhen Academy of Inspection \\ and Quarantine, Technology Center for Animal and Plant Inspection and Quarantine, Shenzhen Customs, \\ 1011 Fuqiang Road, Shenzhen 518010, China; lanwshao@163.com \\ * Correspondence: jidong.gu@gtiit.edu.cn \\ † Current address: Environmental Engineering, Guangdong Technion Israel Institute of Technology, \\ 241 Daxue Road, Shantou 515063, Guangdong, China.
}

Received: 28 September 2020; Accepted: 20 October 2020; Published: 16 November 2020

\begin{abstract}
World cultural heritage suffers from deterioration caused by both natural and anthropogenic processes, among which microorganisms are significantly involved. Among the key issues of this topic, sampling techniques and analytical methods for revealing the microbiome are fundamental to obtaining useful results for understanding the key players and processes involved, and also for effective protection and management of the cultural heritage for humanity. A non-invasive and non-destructive sampling method is required for sampling of cultural properties prior to further analysis of the microbiome. One example is illustrated in this article. For many years, culture-dependent methods had been used before the invention of polymerase-chain reaction (PCR) methods and, more recently, specifically high-throughput next generation sequencing (NGS). NGS reveals the whole microbial community composition and the active microorganisms from genomic DNA and RNA, respectively. The recovered environmental DNA and RNA from samples provide the information on microbial community and composition, and the active members and biochemical processes of the microbial attributes. It should be emphasized that the metabolically-active members of functional microflora in the biofilm or microbiome on cultural heritage must be determined and identified from the RNA-based analysis to gain a substantially important insight of the active biodeterioration processes and also the effectiveness of the conservation strategies. The importance of the culture-independent technique, based on NGS, is that it can be used in combination with the conventional culturing methods to guide the isolation and enrichment of new microorganisms to gain further biochemical insights to advance the role of the specific microbial groups for biodeterioration of cultural heritage. At the same time, effective restoration and maintenance strategies can be formulated for the protection of world cultural heritage.
\end{abstract}

Keywords: cultural heritage; microbiome; biochemical processes; nitrogen cycle; sulfur cycle; acidic attack; stone and rock

\section{Introduction}

Protection of cultural heritage, a social 'resource', has been recognized by many countries as both an economic asset and also an important factor for promotion of social integration [1]. At the same time, world cultural heritage and archaeological sites are the bases for the global tourism industry and economy [2-4]. World cultural heritage is broadly defined by including physical or "tangible" assets, 
including archaeological sites, architecture, monuments, buildings, sculptures etc. and intangible attributes, such as performing arts, oral traditions, rituals etc. Cultural heritage can be physically movable, e.g., books, documents, movable artworks, machines, clothing, and other artifacts worthy of preservation for the future. Meanwhile, the physical non-movable heritage of buildings, architectural ornaments, other historic sites, and monuments is the legacy of history and humanity, allowing selective value to pass from generation to generation. The recognition of the necessity of the historical value of the civilization and of the objects that possess their value and significance promotes the necessity for preservation of culture and heritage for conservation and protection through scientific understanding and better management [5-16].

Conservation science studies the processes that lead to physical changes in historical objects or artifacts that affect their longevity and integrity as a result of various processes or mechanisms of deterioration. These deteriorative mechanisms inform the scientists or conservators about the potential risk factors and strategies to mitigate adverse environmental impacts through management policy to effectively assist long-term conservation [17-22]. Conservation science has gradually evolved into an interdisciplinary research subject by embracing physics, chemistry and biology, microbiology, engineering, materials science, and engineering as well as archaeology, anthropology, and art history [23-28]. In the current conservation research, significant efforts are being made by non-biological analyses, mostly chemistry and material characterization, while an emerging direction has been in analyzing microorganisms on these objects for a more comprehensive knowledge and preservation practice $[29,30]$. Fungi, bacteria, archaea, and lichens have been observed on a variety of historic artifacts such as mural paintings and bas-reliefs in caves, churches and catacombs, stone monuments and architectural surfaces in outdoor environments, and historical/archaeological relics and sites [31-39]. The biodeterioration caused by microorganisms not only influences the aesthetical appearance of the cultural heritage, but also sometimes results in destruction of the structural integrity of the valuable cultural heritage via (bio)chemical processes such as acidification, salt crystallization, calcium carbonate precipitation, water retention, accumulation of pollutants through biofilm formation, and progression [30,38,40-42]. As the world cultural heritage is both unique and irreplaceable, is hardly possible to estimate the economic value of the damage caused by microbial degradation.

Microbiological research on this subject is becoming recognized as an indispensable part of the overall conservation science and the application of current scientific analytical techniques enables microbiologists to determine the microbial community and composition as well as biodeterioration potential of the colonizing microorganisms on the cultural heritage under a given environmental condition. Such knowledge informs how deterioration is likely to occur on cultural heritage and reveals important clues for conservators to monitor or mitigate the adverse effects and to prevent the potential risk from deterioration of historical artworks and objects caused by microorganisms [43,44]. This article offers a synthesis of the important issues of microbiological research for cultural heritage conservation by focusing specifically on sampling and new analytical methods. Furthermore, an outlook is given on the future research needs and developments in this highly important and an emerging research field.

\section{Sampling Techniques}

With respect to cultural heritage, conservation science focuses mainly on protection and maintenance of physical or "tangible" cultural heritage such as artworks, architecture, monuments, and museum collections. The code of ethics in the conservation of cultural heritage outlines that the conservation-restoration of any given physical or "tangible" heritage is to only do the minimum required for preservation [45]. Thus, a detailed diagnostic analysis of the current status of a cultural heritage object by a non-invasive/non-destructive technique is a prerequisite to avoiding unnecessary or potential damage and to keeping the amount of handling to a minimum. Before the advent of the specialized instruments used for conservation studies, visual inspections were the only non-invasive inspection method available in the field of heritage conservation to examine for visual detectable signs of damage, decay, or deterioration. Because of the methodological limitations of visual inspection, 
the earliest conservation studies could not yield the detailed quantitative information on deterioration processes and mechanisms, and always led to inconclusive results [46,47]. Microorganisms were not previously considered in this field. Currently, a number of generic or specialized research techniques have begun to be applied to heritage conservation studies to provide the powerful means to analyze the current state of an object for preservation or to detect any products of deterioration and decay that ought to be removed or cleaned. On the collection of samples involved in heritage conservation studies, the dogma which outlines the best practice for conservators and scientists alike for scientific analysis is "non-invasive and non-destructive method for bio-molecular and chemical analysis that requires very small quantities of sample from inconspicuous locations on artworks and objects" [48]. As the requirement for sampling techniques has suggested, any analytical techniques to be used must be highly sensitive, requiring minimum amounts of sample or none at all. Because of this, conservation microbiologists need to maintain a close communication with conservators, curators, and heritage authorities and work closely on research projects to determine the most appropriate sampling schemes and the proposed measurements prior to carry out the sampling.

A significant proportion of the cultural heritage relics and physical objects that suffer varying levels of biodeterioration caused by microorganisms have been rescued by salvage archaeology effort. Under non-ideal preservation and storage conditions, artifacts that have always been in storage such as archives, books, documents and paintings, and their constituent materials, both organic and inorganic, can provide a suitable surface or substratum for colonization by different types of microorganisms to form biofilm $[30,38,49,50]$. Microorganisms grow on the surface of artifacts mainly in clusters or aggregates called microbial biofilms, that have the potential to cause adverse reactions chemically or biochemically with cultural heritage objects $[30,31,36]$. A microbial biofilm is a collection of microbial cells and extracellular polymer substances (EPSs) together adhering onto a solid substratum surface (Figure 1). They are ubiquitous and play an important role in ecosystems. Numerous studies have confirmed that biofilms are not simple microbial assemblages, but have well-defined spatial distribution characteristics and microbial community composition and structures to assist in their ecological functions [33,51]. Spatial microbial distribution has been reported in some environmental biofilms, especially in aquatic ecosystems [52-54]. Microorganisms communicate via chemical cues prior to and during the biofilm formation. A stratified bacterial structural organization exhibited in biofilms has been reported on the limestone of historical monuments at a Mayan site [55], and on sandstone of Angkor temples with both spatial and temporal dynamics [33,56]. These adverse (bio)chemical reactions range from simply stains to acidification, discoloration, and utilization of the materials as nutrients and weaken the structure causing further disintegration and delamination.

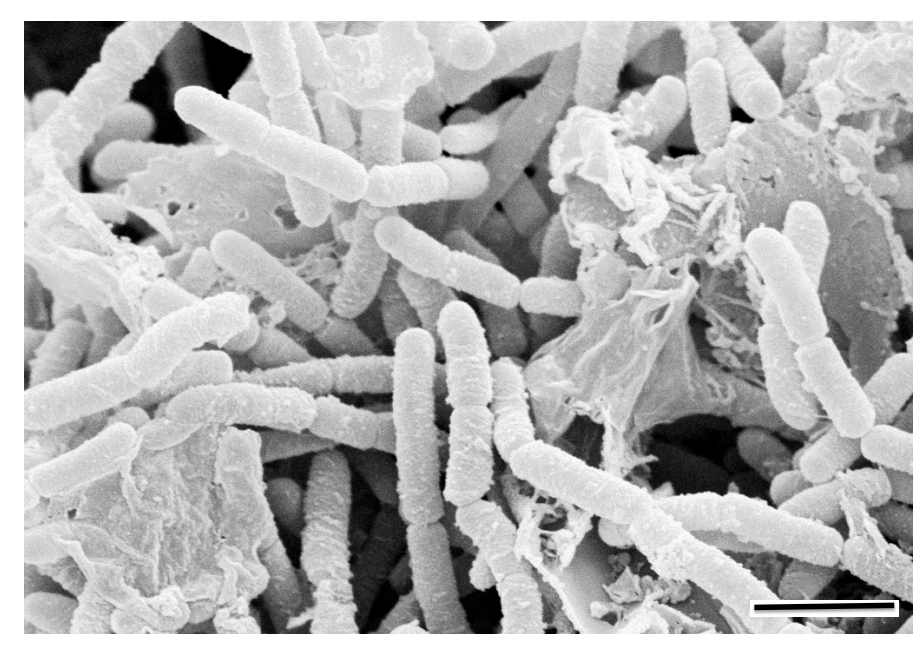

Figure 1. A SEM micrograph showing a matured biofilm consisting of both grown cells and extracellular polymeric materials on surface of a rock under moist conditions (scale bar, $2 \mu \mathrm{m}$ ). 
Earlier sampling techniques required relatively large amount of materials to be taken from the object before chemical and especially microbiological analyses could be carried out due to the lower sensitivity of the analytical techniques involved. Because of this, the focus of this article is on the current sampling techniques with a minimum and non-invasive approach coupled with highly-sensitive microbiological analysis. Currently, a slightly different version of the same principle has been developed as a sampling technique using sterilized plastic adhesive sheet or tape to remove microbial biofilms and loosely-attached materials including degradation products from surfaces, regardless of the surface physical morphologies and material types [57] (Figure 2). This sampling device was initially developed by the Japan Space Agency for sampling surfaces for microbiological assessment on the International Space Station and then it was then adopted in the cultural heritage conservation work at Angkor for more than a couple of decades [31,33,58-62]. This sampling technique, with some small variations, has also been used in Europe for microbiological analysis of cultural heritage (Urzi and De Leo, 2001). The device, consisting of an adhesive on a plastic sheet and a supporting paperboard, is made under sterile conditions, and can be conveniently carried to sampling locations. At the sampling site, after peeling the paperboard from the adhesive and attaching the adhesive surface to the sampling location to obtain the materials from the surface onto adhesive (Figure 3), further microbiological analyses can be carried out on the materials picked up on the adhesive. This sampling technique shows a higher recovery rate for microbial populations than the conventional cotton swab method [63] or stamp agar [57]. By applying the adhesive technique in sampling, samples could be collected as many times as required at a selected location to obtain spatial distribution information and composition of the microbial community from the sandstone bas-relief wall of Bayon temple of Angkor Thom in Cambodia [31,33]. Specifically, samples were analyzed to establish the relationship between the specific colors on the sandstone wall and the dominant microorganisms [33]. By working closely with Apsara Authority and the Ministry of the Environment, Kingdom of Cambodia, this sampling technique was systematically applied in the conservation and protection research of Angkor monuments over the past 20 years or more to accumulate data on multiple dimensions of the research objectives $[31,33,51]$.
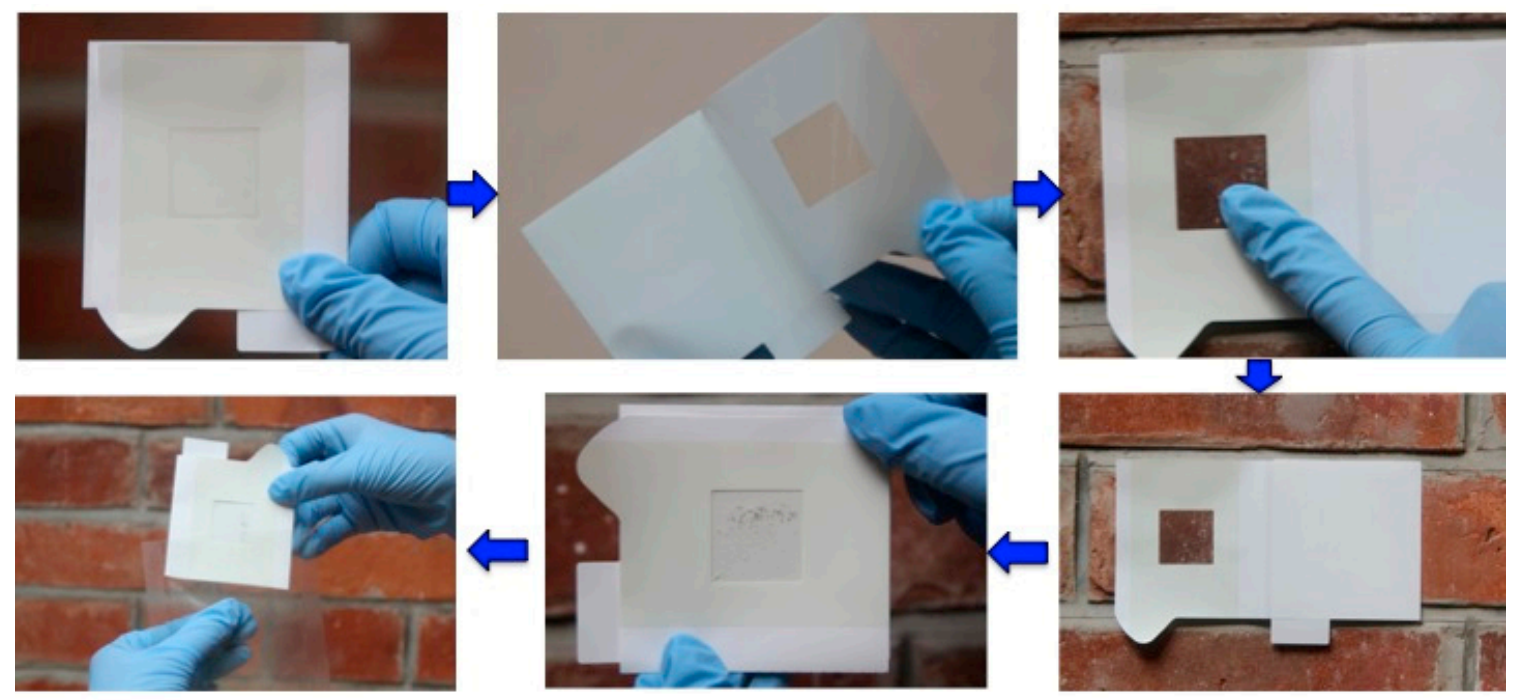

Figure 2. The adhesive sheet sampling device developed for non-invasive/non-destructive sampling from various solid surfaces. The adhesive sheet can collect biofilm (the microbial community and the decomposed materials on the solid surface) from the surface to the deepest layer by a series of continuous peeling-off sampling of the biofilm at the same sampling position to analyze the stratified microbiome structure. 


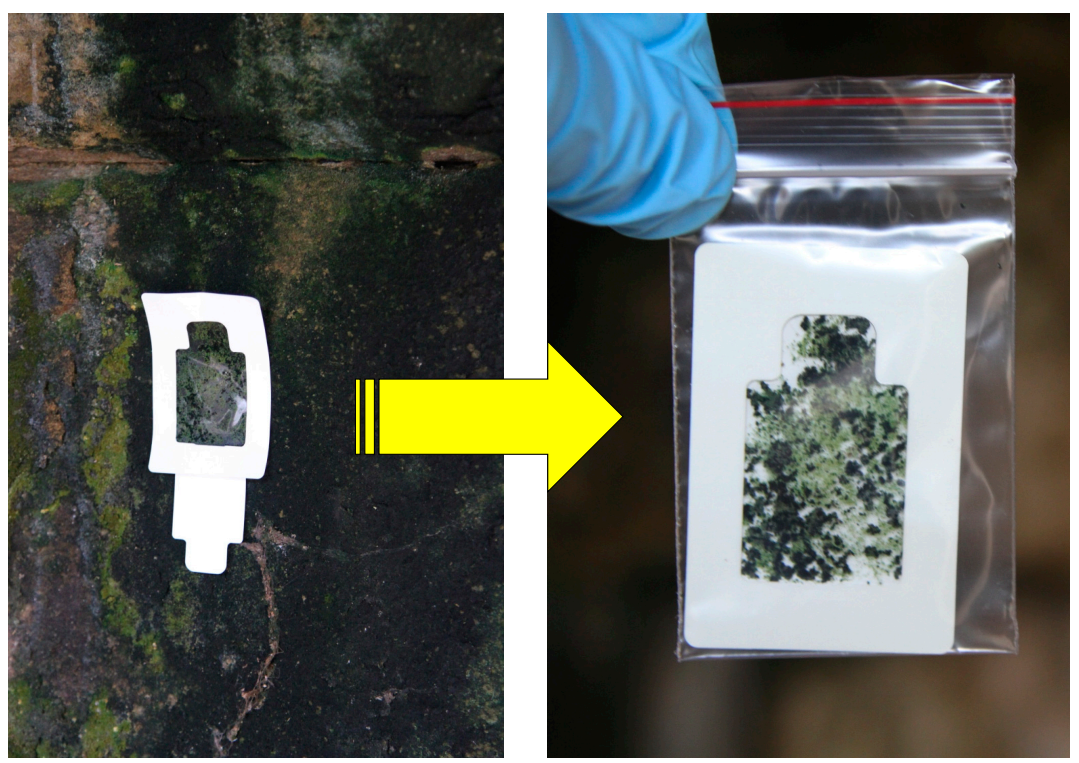

Figure 3. The adhesive sampling device in a slightly different configuration from that shown in Figure 2 used for sampling the surface colonizers on sandstone wall of Angkor temple in Cambodia and then transferred into a sterile plastic bag ready for preservation and transportation.

The adhesive sampling technique allows analysis of samples for microbial community and composition on these sheets afterward [31,33]. For example, the characteristics of the stratified structure of bacteria in the biofilm were analyzed and characterized by using 16S rRNA-based PCR-denaturing gradient gel electrophoresis (DGGE) analyses among bacterial communities after non-destructive collection of biofilm samples onto adhesive sheets from the sandstone surface of Bayon temple at Angkor Thom, Cambodia [33]. The study disclosed a rich community of bacteria, especially cyanobacteria-related bacteria, on the outer surface layer of the biofilm, but fewer in the lower layer; while Chloroflexi-related bacteria appeared only in the lower layer of the biofilm. A similar distribution of bacterial structure has already been reported in microbial mats in a hot spring which was very rich in cyanobacteria near the surface and Chloroflexi in deeper layers [64-67]. Considering the differences between the optical absorption spectra of the Chloroflexi and Cyanobacteria together with the phylum Chloroflexi, which are an order of heterotrophic bacteria and an order of anoxygenic phototrophs [67-69], these results suggest that the bacteria residing within the biofilm are very specific spatially, depending on the availability of light and organic nutrients and the oxygen concentration. The biofilm formation and development on cultural heritage surfaces affect not only the aesthetic appearance of the artistic presentation and clarity but also the integrity of its underling materials by the colonization of microorganisms, and biofilm formation and development $[30,31,40,49,70]$. Information about the spatial distribution characteristics and microbial compositional structures of the microbial communities in the biofilm is therefore indispensable for understanding the microbial community involved in the biofilm formation and also controlling biofilm colonization of the cultural heritage.

\section{Microbiome Analysis by Culture-Independent Methods}

Knowledge of the microorganisms inhabiting cultural heritage and their involvement in the material deterioration is basic for conservators to formulate actions to preserve and protect cultural heritage. For decades, culture-dependent approaches have been applied to isolate and identity any culturable microorganisms from the microbiome inhabiting cultural heritage [60-62,71,72], but this approach has many shortcomings. Many naturally-occurring microorganisms that can be cultured in laboratory media are selected by the medium composition and also the culturing conditions [73], not the dominant members in the niche or in situ conditions, so the subsequent results of the 
physiology and biochemistry of these microorganisms have very limited relevance or value to the whole community composition and the biochemical processed involved. In addition, microorganisms cultured under laboratory conditions experience much higher concentrations of nutrients than the ambient environmental conditions on the cultural heritage, and this critical factor has been largely ignored in practice (Figure 4). The microbiome on sandstone is dominated by halophile and microorganisms are capable of adaptation to the local conditions and also enter a physiological state, called viable but non-culturable (VNC) state under adverse condition of nutrient limitation and low temperature [74,75]. Under natural condition, a complex microbial community is the normal state rather than the pure culture of a single species in artificial medium. The halophilic condition on sandstone selects relevant microorganisms and similarly antibiotic-resistant populations can be developed after such chemicals have been applied for a while to alter the indigenous microbiome.

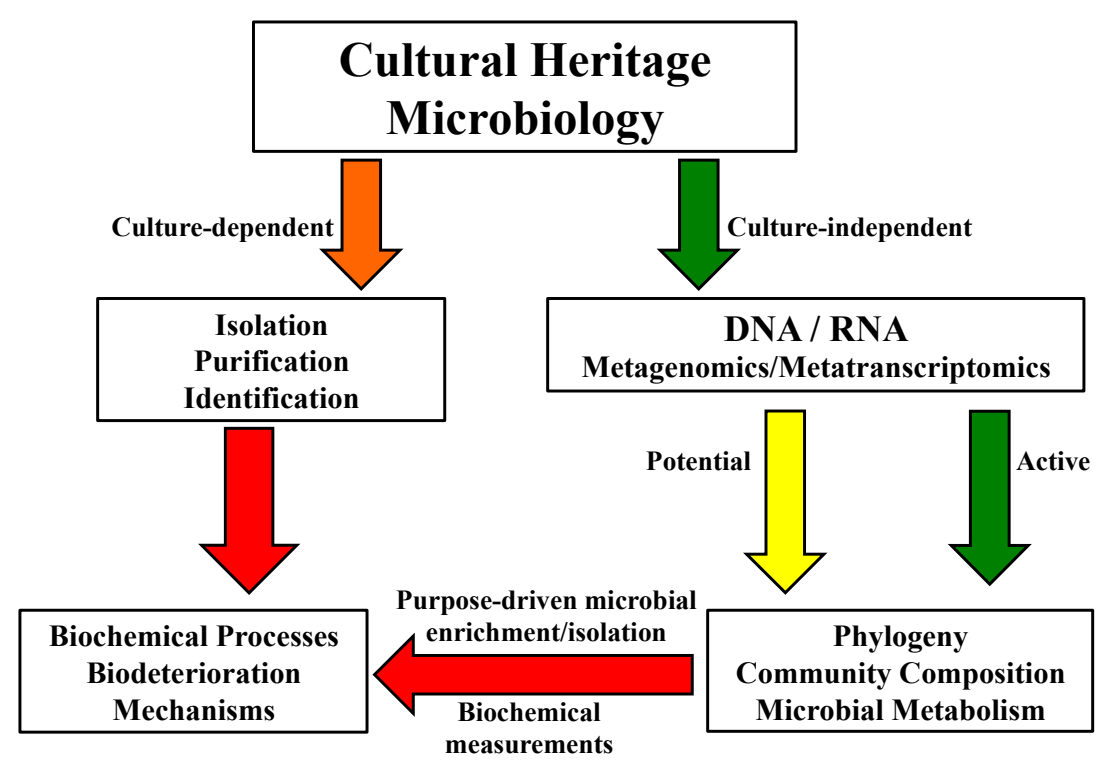

Figure 4. A schematic diagram showing the general framework in microbiological analyses of cultural properties and protection.

Culturing of microorganisms is a critically-important issue in environmental microbiology and it prevents researchers gaining further detailed insights into the biochemical function from members of a complex microbial community through isolation and pure culture techniques [73]. On the other hand, the development and application of DNA-based molecular methods in conservation sciences overcomes the culture-dependent limitations to reveal the microbial diversity and composition of the whole microbiome with greater depth on cultural heritage of any material type and at any time. Earlier molecular techniques used in conservation sciences include the genetic fingerprinting analyses such as DGGE/temperature gradient gel electrophoresis (TGGE), amplified ribosomal DNA restriction analysis (ARDRA), single-strand conformation polymorphism (SSCP), terminal restriction fragment length polymorphism (t-RFLR), and automated ribosomal intergenic spacer analysis (ARISA) after PCR [33]. For instance, a previous study investigated the abundance and diversity of microbial communities thriving on damaged mural paintings in Portugal, by combining culture-dependent methods and culture-independent methods, such as DGGE. However, it was found that the coupling of culture-dependent methods and DGGE still did not yield enough information to understand the abundance and the diversity of microorganisms present on the wall paintings [76]. Because of the methodological limitation and sensitivity of these genetic fingerprinting analyses, they failed to identify different members of a particular microbial group taxonomically to a satisfactory resolution with confidence. 


\subsection{High Through-Put Sequencing}

The culture-independent methods based on PCR amplification of specific target genes, commonly the 16S rRNA gene, which serves as an evolutionary chronometer and allows phylogenetic analysis of obtained sequences from the microbial community [77], are becoming a routine technique used with a sharp increase of its acceptance today. Initially, the DNA-based techniques were applied to single colonies or libraries of PCR-amplified nucleotide sequences from environmental samples, after successful cloning of the single PCR products, but in recent years, the application of next generation sequencing (NGS) technology to microbial communities has revolutionized research on ecological microbiology, enabling, at an affordable cost, both deep information and also large-scale sequencing of DNA samples without culturing and cloning. This simplifies the analytical procedures involved and also makes this technology accessible based on paid-for-service. Metagenomics for the characterization of microbial community phylogeny and diversity is a new line of molecular microbiological methods based on genomic DNA extraction directly from environmental samples and then NGS technology to obtain the short reads of nucleotides for further assembly and analysis [78-80].

Metagenomic technologies can be either target-specific or non-specific. For the target-specific ones, the microbial community of bacteria and archaea is revealed based on the 16S rRNA gene, and that of eukaryotes based on the 18S rRNA or additional genes. Zhang et al. [31] investigated the bio-erosion of the sandstone of the Royal Palace of Angkor Thom and the temple Beng Mealea using the NGS targeting the 16S rRNA gene with samples of biofilm and exfoliated materials to obtain phylogeny and diversity information of the bacterial community in them. The results of this study using the adhesive sampling technique revealed that a higher bacterial diversity was detected in exfoliated sandstone materials than in the biofilms, but the diversity of bacteria was lowest in the lower layers of the biofilm after repetitively sampling at a selective location (discussed above). Firmicutes and Gemmatimonadetes were the dominant phyla and were detected only in exfoliated materials, while Cyanobacteria, Chloroflexi, and unassigned bacteria were more abundant in the biofilms. The results of this study suggested a microbial specificity on the sandstone monuments by the nature of the sample types and the different degree of deterioration. Biofilms grown on the surface of sandstone are in constant contact with the underlying inorganic substratum, the shortage of organic nutrients resulting in lower diversity of the community of heterotrophic bacteria adhering on the sandstone surface. Moreover, Cyanobacteria and Chloriflexi were identified as the key photoautotrophic microorganisms colonizing the surface of the sandstone. They appeared widely in the biofilms of Angkor monuments with a strong ability for utilizing direct or indirect sunlight, resistance to the high temperature, and the ability to survive the hypersaline environment of sandstone niche $[33,38,56,62,81]$. The active metabolism of these autotrophic microorganisms results in the fixation of the inorganic $\mathrm{CO}_{2}$ as a carbon source and the ability to modify the surface layer for retention of water, providing opportunities for subsequent colonization by the heterotrophic bacteria and fungi $[38,40,56,58,59,82]$. Then, a diverse and stable microbial community can be formed on the exfoliation sandstone materials, and the microbial activity and abundant metabolites further accelerate the attack of the sandstone. Although the target-specific methods can amplify and sequence marker regions of the ribosomal DNA to obtain a genus-level picture of the microorganisms present in different environmental samples, the targeted metagenomic analysis alone could not yield enough information about the genes and the biochemical functions in a microbial community because of the lower depth of sequencing [83]. However, the target non-specific metagenomics approaches, with the rapid technological advancement in high-throughput NGS, as well as bioinformatics data processing and analysis, can extract strain-level information of the genes and the biochemical functions in a microbial community for a better understanding of the attacking mechanisms of microorganisms on historical materials. Microorganisms interact with underlying materials and with other microorganisms, e.g., biofilms, and such information can be very specific in evaluating the outcomes of the maintenance and conservation treatments on the function and community shifts of the microbiome on cultural heritage. A recent microbiological research studied microbial phylogenetic composition as well as biochemical capabilities of the microbiome inhabiting the sandstone surfaces 
of the Preah Vihear temple by using this non-targeted metagenomic approach. The results of this deep metagenomics analysis provided a detailed description of the microflora present on the surface of this cultural heritage [84]. The results indicated the presence of biochemical processes for carbon sequestration, and nitrogen and sulfur metabolism were identified as potentially the active microbial biochemical processes on the sandstone surface at this site. Specifically, the identified acid-producing biochemical processes of sulfur-oxidizing bacteria and ammonia-oxidizing bacteria and archaea suggest that the microbial flora on the sandstone surface participate in the deterioration of sandstone cultural heritage by producing acids $[32,84,85]$. High-throughput NGS is a powerful method and has the advantage of characterizing the microbial community phylogeny and diversity quickly, accurately, and economically with a deeper data recovery $[31,86]$. For investigations of microbiome of cultural heritage and the surrounding environment, where the biomass is relatively lower and the sample size is a serious concern due to the value of the object concerned, NGS is a good candidate method for such microbiological analysis to obtain the basic necessary data with high confidence as a first step.

\subsection{Genomic DNA vs. RNA}

The total microbial biomass is a useful indicator of microbial population and contamination on solid surfaces, but the viable microbes are important estimators of microbial activity and metabolic potential. The expression analysis of genes can yield detailed information about the metabolicallyactive members and microbial metabolic state of the microbiome and about the microbe-mediated biodeterioration process and potential, for example, following the microbial metabolic activities of ammonia oxidation by bacteria and archaea $[32,85]$ and sulfur oxidation $[60,61]$ on cultural relics with RNA. Assessment of the metabolically-active members or groups in the microbial community is a more selective and specific approach to identifying the specific culprits than the overall information recovered from the genomic DNA of samples.

Currently, it is necessary to determine the level of metabolic or physiological activity of specific functional microflora in biofilm or microbiome on cultural heritage because this information is the basis for conservators and scientists to gain a deeper understanding of the biodeterioration processes, to monitor the effectiveness and success of the conservation treatments, and to develop alternative and non-toxic conservation strategies to inhibit or slow down microbe-mediated biodeterioration (Figure 4). Although real-time quantitative PCR (RT qPCR) is currently a routine tool for solving many scientific problems, it is not useful for routine monitoring of biodeterioration and has been used only occasionally on samples of cultural heritage. In a recent study, the community of ammonia-oxidizing microorganisms as a biodeteriogen on the Angkor monuments, the ammonia-oxidizing archaea (AOA), were determined to be the more active members over ammonia-oxidizing bacteria $(\mathrm{AOB})$ in the nitrifying reaction of the microbiome on Angkor monuments. They can play an important role in biodeterioration according to the results from the RT qPCR analyzing the expression of amoA gene of samples [32]. Further confirmation of the biochemical capabilities are still expected to establish the microbial transformation processes responsible for destruction of materials (see next section).

Gene-by-gene molecular analysis is too time-consuming and requires a high level of technical skill in conservation science. As a result, it is not cost-effective in application. Recent metatranscriptomics approaches that rely on NGS platforms offer more possibilities for understanding the metabolic pathways and the activity of the specific metabolic processes within microbial communities $[30,83,87]$. However, metatranscriptomics approaches applied to the study of biodeterioration of cultural heritage are still in their infancy and their application in conservation science is not yet widely available. In general, the costs for molecular analysis are going down rapidly and operational issues with RNA protection and extraction are also improving. Bioinformatics tools to process the metatranscriptome datasets are also becoming routine for processing to microbial communities and gene assembly associated with biodeterioration. 


\section{Biochemical Functional Approaches}

Both growth on surface as biofilms and specific metabolic activity (i.e., acidification) of the active microorganisms are important information for the understanding and prediction of damage to the materials of cultural heritage. Earlier investigations suffered from the isolation of limited numbers of cultured bacteria in pure cultures from the general community of microorganisms due to the technical means available. There were several early attempts to quantify the activity of the microbiome based on chemical reactions $[30,88]$. Detection and quantifying ATP can be used as an estimation of biological activity on surfaces like paper, paintings, or other materials in swab samples using the commercially-available products of luminometers $[89,90]$. However, the active microbial groups and members on cultural heritage may not be the directly destructive ones responsible for the damage caused to the cultural heritage and the general purpose-driven biochemical analysis of the samples from cultural heritage only provides limited insights because a close relationship between the destruction and specific microbial group cannot be established.

The "tangible" or physical cultural heritage, no matter whether moveable artifacts or immovable historic sites, is in a constant state of chemical transformation and equilibrium with the surrounding environmental conditions [91] and selective biochemical processes accelerate the chemical transformation of the underlying materials given the colonization by microorganisms. Selective microbial groups carry out the important biochemical transformation reactions with high specificity regulated by relevant genes and the corresponding enzymes/proteins. It is known that autotrophic microorganisms are pioneering organisms that colonized the bare surfaces of sandstone when the cultural heritage was initially built, but the roles of these microorganisms are not straight-forwardly detrimental because their protective role for the sandstone, for example from lichen, was significant in the beginning [40]. After sequestration of atmospheric $\mathrm{CO}_{2}$ onto the surface as biomass, the physical surface properties of the heritage are significantly altered, allowing for diversification of the microbial community with different physiological functions and also for accumulation of pollutants to promote the degradative microorganisms [63]. Information on these has been reviewed recently [40,92].

More recently, $\mathrm{NO}_{3}{ }^{-}$production and accumulation of the nitrogen cycle have been widely observed and confirmed on Angkor sandstone monuments under the tropical climate in Cambodia [32,85]. The concentration of $\mathrm{NO}_{3}{ }^{-}$is positively correlated with the acidity and $\mathrm{pH}$ value, among the different environmental variables of these sandstone monuments. The constant acidification on the cultural heritage initiates and accelerates the dissolution of mineral constituents in the sandstone and produces the phenomenon of salt attack by crystallization/efflorescence on/in the substratum material which leads to structural weakening and crack formation of the cultural heritage $[16,29,30,35,70,93]$. After successive sampling over a 3-year period and analyses of the ammonia-oxidizing archaea (AOA) and bacteria (AOB) by both genomic DNA and RNA from samples for real-time PCR, AOA was apparently higher than $\mathrm{AOB}$ on these sandstone monuments and detection of $\mathrm{NO}_{3}{ }^{-}$was successful $[32,85]$. Furthermore, a stable isotope tracer experiment by addition of the ${ }^{15} \mathrm{~N}$ in the chemical forms of $\mathrm{NH}_{4}{ }^{+}$ or $\mathrm{NO}_{3}{ }^{-}$was initiated and incubated with samples collected from several Angkor monuments to quantify the nitrogen transformation rate from nitrate removal as nitrogen gas and determine the contribution of the microbial community to the removal of available nitrate. The results of this study revealed that the heterotrophic denitrification $\left(\mathrm{NO}_{3}{ }^{-} \rightarrow \mathrm{NO}_{2}{ }^{-} \rightarrow \mathrm{NO} \rightarrow \mathrm{N}_{2}\right)$ activity in the microbiome of the sandstone monument was low, and the activity of anammox $\left(\mathrm{NH}_{4}{ }^{+}+\mathrm{NO}_{2}{ }^{-} \rightarrow \mathrm{N}_{2}\right)$ in the sample from the monument was negligible [84]. According to data in this study, the nitrate removal reaction of denitrification was active, but not strong enough to remove the produced and accumulated $\mathrm{NO}_{3}{ }^{-}$ because ammonia oxidation is aerobic while denitrification is anoxic. The physical conditions of available oxygen most likely play the regulation role, resulting in the accumulation of nitrate on the Angkorian sandstone.

Sulfur is also involved in the sandstone attack through microbial transformation of $\mathrm{S}$ at different valent states. Fusarium sp. and Mycobacterium spp. were isolated from decayed materials of the sandstone monuments and elucidated their metabolic capability of sulfur oxidation to acidic sulphate 
via chemolithoautotrophic metabolism in laboratory experiments [61,62]. The metabolic products of these sulfur-oxidizing bacteria are capable of producing inorganic acid through oxidation of $S$ and the acidity in the form of $\mathrm{H}^{+}$interacts with minerals causing dissolution and re-crystallization regulated through water retention and loss by natural force, resulting in structural weakening of the stone material integrity and disintegration $[29,40,70]$. These findings suggested that these sulfur-oxidizing Fusarium sp. and Mycobacterium spp. participate in the deterioration process (i.e., acidification) of the sandstone monuments under tropical conditions. The accumulation of acids, $\mathrm{NO}_{3}{ }^{-}$and $\mathrm{SO}_{4}{ }^{2-}$, which are corrosive to the inorganic material substratum of the cultural heritage, can be observed by microbially-mediated biochemical transformations.

As the former section stated, NGS techniques can provide thorough information of the microbial community and composition inhabiting cultural heritage to allow for identifying of the microorganisms without culturing them, which cannot be achieved by a culture-dependent approach. However, the involvement of the new microorganisms in the biodeterioration needs further careful verification even if high percentages of sequence reads with a metabolic potential are detected. The results of NGS-based investigations can provide useful information for the purpose-driven biochemical functional analysis and identify the physiological characteristics of the abundant genes and associated groups for developing culturing strategies to enrich and isolate the implicated members for further verification of their biochemical and ecophysiological roles in deterioration (Figure 4). Therefore, NGS technology can be employed to obtain basic information to assist in further research directions and strategies to directly confirm the scientific questions prior to culture-based strategies or activity-based biochemical functional analysis. It is also important to use NGS to gain an overview or summary of the whole microbial community prior to a genuine scientific question being executed. In doing this way, culture-dependent and -independent methods can be integrated effectively to advance scientific research on cultural heritage and also provide useful understanding for protection and management.

\section{Summary and Future Perspectives}

Current research addressing the issue of biodeterioration of cultural heritage needs to focus on sampling methods and appropriate analytical techniques used afterward. Application of non-invasive/non-destructive sampling strategies is required in microbiological studies for conservation. The NGS-based metagenomics and metatransriptomics should be applied to the study of biodeterioration of cultural heritage for the microbial structure (especially spatial distribution structure) of the microbiome and the potential of specific microbial groups and microbe-mediated transformation processes contributing to biodeterioration. The NGS-based results can provide sound basis for the purpose-driven biochemical functional analysis or develop enrichment and culturing strategies to isolate the implicated groups of microorganisms with significant roles in biodeterioration. There are apparent challenges for investigations to develop the purpose-specific biochemical functional analysis for measuring the valid deterioration effects of microbiome and for enhancing knowledge of cultivation of microorganisms from a specific material.

Delineation of the processes and mechanisms involved for (bio)deterioration should be the basis for understanding the current status with a selective cultural heritage. When the destructive reactions are known and also the specific microorganisms responsible for the processes, remediation strategies and management plan can be proposed accordingly [94]. Sulfur-driving acid production can be dealt with from restriction on fuel quality and air quality mandate in policy and management while intervention on site can be carried out through mineralization to immobilize produced $\mathrm{SO}_{4}{ }^{2-}$. $\mathrm{NO}_{3}{ }^{-}$is an issue that is more difficult to address than $\mathrm{SO}_{4}{ }^{2-}$, but an effective way to deal with it should be to focus on the source of $\mathrm{NH}_{4}{ }^{+}$to eliminate its contribution from the beginning. In addition, new emerging science on materials can also take an important role in the effective protection and management of culture heritage to decrease the detrimental contribution from microorganisms and their biochemical 
capabilities. Overall, protection of cultural heritage is a complex subject and synergies of different subjects will contribute to the advancement of this field for both basic knowledge and also applications.

Author Contributions: Conceptualization, W.L. and J.-D.G.; writing—original draft preparation, X.D.; writingreview and editing, X.D., W.L. and J.-D.G.; supervision, J.-D.G.; project administration and funding acquisition, W.L. and J.-D.G. All authors have read and agreed to the published version of the manuscript.

Funding: This research was funded by Shenzhen Scientific Project Fund (JCYJ20170410103015603), and Hong Kong RGC GRF Grant (No. 17302119).

Acknowledgments: This project was financially supported by Shenzhen Scientific Project Fund (JCYJ20170410103015603), and Hong Kong RGC GRF Grant (No. 17302119). We would like to thank the Apsara Authority of the Kingdom of Cambodia for permission to conduct sampling and research for more than a decade, Ka Hong Cheung for the SEM in Figure 1, and Lin Gao for help with the photographs presented in Figure 2.

Conflicts of Interest: The authors declare no conflict of interest.

\section{References}

1. Ertan, T.; Egercioglu, Y. The Impact of UNESCO World Heritage List on Historic Urban City Centers and Its Place in Urban Regeneration: The Case of Melaka, Malaysia and Tire, Turkey. Procedia Soc. Behav. Sci. 2016, 216, 591-602. [CrossRef]

2. Silverman, H.; Ruggles, D.F. Cultural Heritage and Human Rights; Springer: New York, NY, USA, 2007; p. ix. 205p.

3. Hilbert, G.S. Protection against Theft and Willful Damage + Museum Security. Museum 1985, 37, 115-118. [CrossRef]

4. Martin-Sanchez, P.M.; Novakova, A.; Bastian, F.; Alabouvette, C.; Saiz-Jimenez, C. Use of Biocides for the Control of Fungal Outbreaks in Subterranean Environments: The Case of the Lascaux Cave in France. Environ. Sci. Technol. 2012, 46, 3762-3770. [CrossRef]

5. Tanselle, G.T. Literature and Artifacts; Bibliographical Society of the University of Virginia: Charlottesville, VA, USA, 1998; p. xvii. 356p.

6. Mckenna, G.A. Security and the Spirit of Cooperation—Protection Systems in Museums Large and Small. Mus. News 1979, 58, 7-9.

7. Skaggs, D. An Ounce of Prevention-A Handbook on Disaster Contingency Planning for Archives, Libraries and Record Centers-Barton, Jp, Wellheiser, Jg. Am. Arch. 1986, 49, 471-472.

8. Castanier, S.; Le Metayer-Levrel, G.; Perthuisot, J.P. Ca-carbonates precipitation and limestone genesisThe microbiogeologist point of view. Sediment. Geol. 1999, 126, 9-23. [CrossRef]

9. Magaudda, G. The recovery of biodeteriorated books and archive documents through gamma radiation: Some considerations on the results achieved. J. Cult. Herit. 2004, 5, 113-118. [CrossRef]

10. Fernandes, P. Applied microbiology and biotechnology in the conservation of stone cultural heritage materials. Appl. Microbiol. Biotechnol. 2006, 73, 291-296. [CrossRef]

11. Rives, V.; Garcia-Talegon, J. Decay and conservation of building stones on cultural heritage monuments. Mater. Sci. Forum 2006, 514-516, 1689-1694. [CrossRef]

12. Mesquita, N.; Portugal, A.; Videira, S.; Rodriguez-Echeverria, S.; Bandeira, A.M.L.; Santos, M.J.A.; Freitas, H. Fungal diversity in ancient documents. A case study on the Archive of the University of Coimbra. Int. Biodeterior. Biodegrad. 2009, 63, 626-629. [CrossRef]

13. Pinar, G.; Jimenez-Lopez, C.; Sterflinger, K.; Ettenauer, J.; Jroundi, F.; Fernandez-Vivas, A.; Gonzalez-Munoz, M.T. Bacterial Community Dynamics During the Application of a Myxococcus xanthus-Inoculated Culture Medium Used for Consolidation of Ornamental Limestone. Microb. Ecol. 2010, 60, 15-28. [CrossRef] [PubMed]

14. Gu, J.-D.; Kigawa, R.; Sato, Y.; Katayama, Y. Addressing the microbiological problems of cultural property and archive documents after earthquake and tsunami. Int. Biodeterior. Biodegrad. 2013, 85, 345-346. [CrossRef]

15. Pinar, G.; Garcia-Valles, M.; Gimeno-Torrente, D.; Fernandez-Turiel, J.L.; Ettenauer, J.; Sterflinger, K. Microscopic, chemical, and molecular-biological investigation of the decayed medieval stained window glasses of two Catalonian churches. Int. Biodeterior. Biodegrad. 2013, 84, 388-400. [CrossRef] [PubMed] 
16. Pinar, G.; Piombino-Mascali, D.; Maixner, F.; Zink, A.; Sterflinger, K. Microbial survey of the mummies from the Capuchin Catacombs of Palermo, Italy: Biodeterioration risk and contamination of the indoor air. FEMS Microbiol. Ecol. 2013, 86, 341-356. [CrossRef] [PubMed]

17. Nitterus, M. Ethanol as fungal sanitizer in paper conservation. Restaurator 2000, 21, 101-115. [CrossRef]

18. Nitterus, M. Fungi in archives and libraries-A literary survey. Restaurator 2000, 21, 25-40. [CrossRef]

19. Bohm, C.B.; Zehnder, K.; Domeisen, H.; Arnold, A. Climate control for the passive conservation of the Romanesque painted wooden ceiling in the church of Zillis (Switzerland). Stud. Conserv. 2001, 46, 251-268. [CrossRef]

20. Morgan, G.C. The Materials of Cultural Heritage in their Environment. Mediev. Archaeol. 2007, 51, 400-401.

21. Bastian, F.; Alabouvette, C. Lights and shadows on the conservation of a rock art cave: The case of Lascaux Cave. Int. J. Speleol. 2009, 38, 55-60. [CrossRef]

22. Cappitelli, F.; Fermo, P.; Vecchi, R.; Piazzalunga, A.; Valli, G.; Zanardini, E.; Sorlini, C. Chemical-physical and Microbiological Measurements for Indoor Air Quality Assessment at the Ca' Granda Historical Archive, Milan (Italy). Water Air Soil Pollut. 2009, 201, 109-120. [CrossRef]

23. Gheyle, W.; Dossche, R.; Bourgeois, J.; Stichelbaut, B.; Van Eetvelde, V. Integrating Archaeology and Landscape Analysis for the Cultural Heritage Management of a World War I Militarised Landscape: The German Field Defences in Antwerp. Landsc. Res. 2014, 39, 502-522. [CrossRef]

24. Adamo, A.M.; Giovannotti, M.; Magaudda, G.; Zappala, M.P.; Rocchetti, F.; Rossi, G. Effect of gamma rays on pure cellulose paper as a model for the study of a treatment of "biological recovery" of biodeteriorated books. Restaurator 1998, 19, 41-59. [CrossRef]

25. Baer, N.S. Microclimate for cultural heritage. Stud. Conserv. 2000, 45, 143. [CrossRef]

26. Allsopp, D.; Seal, K.J.; Gaylarde, C.C. Introduction to Biodeterioration, 2nd ed.; Cambridge University Press: Cambridge, UK; New York, NY, USA, 2004; p. xii. 237p.

27. Albertano, P.; Bruno, L.; Bellezza, S. New strategies for the monitoring and control of cyanobacterial films on valuable lithic faces. Plant. Biosyst. 2005, 139, 311-322. [CrossRef]

28. Saiz-Jimenez, C.; Miller, A.Z.; Martin-Sanchez, P.M.; Hernandez-Marine, M. Uncovering the origin of the black stains in Lascaux Cave in France. Environ. Microbiol. 2012, 14, 3220-3231. [CrossRef]

29. Scheerer, S.; Ortega-Morales, O.; Gaylarde, C. Microbial Deterioration of Stone Monuments-An Updated Overview. Adv. Appl. Microbiol. 2009, 66, 97-139. [CrossRef]

30. Sterflinger, K.; Pinar, G. Microbial deterioration of cultural heritage and works of art-Tilting at windmills? Appl. Microbiol. Biotechnol. 2013, 97, 9637-9646. [CrossRef]

31. Zhang, X.W.; Ge, Q.Y.; Zhu, Z.B.; Deng, Y.M.; Gu, J.-D. Microbiological community of the Royal Palace in Angkor Thom and Beng Mealea of Cambodia by Illumina sequencing based on 16S rRNA gene. Int. Biodeterior. Biodegrad. 2018, 134, 127-135. [CrossRef]

32. Meng, H.; Katayama, Y.; Gu, J.-D. More wide occurrence and dominance of ammonia-oxidizing archaea than bacteria at three Angkor sandstone temples of Bayon, Phnom Krom and Wat Athvea in Cambodia. Int. Biodeterior. Biodegrad. 2017, 117, 78-88. [CrossRef]

33. Kusumi, A.; Li, X.S.; Osuga, Y.; Kawashima, A.; Gu, J.-D.; Nasu, M.; Katayama, Y. Bacterial Communities in Pigmented Biofilms Formed on the Sandstone Bas-Relief Walls of the Bayon Temple, Angkor Thom, Cambodia. Microbes Environ. 2013, 28, 422-431. [CrossRef]

34. Ettenauer, J.; Sterflinger, K.; Pinar, G. Cultivation and molecular monitoring of halophilic microorganisms inhabiting an extreme environment presented by a salt-attacked monument. Int. J. Astrobiol. 2010, 9, 59-72. [CrossRef]

35. Pinar, G.; Ripka, K.; Weber, J.; Sterflinger, K. The micro-biota of a sub-surface monument the medieval chapel of St. Virgil (Vienna, Austria). Int. Biodeterior. Biodegrad. 2009, 63, 851-859. [CrossRef]

36. Saarela, M.; Alakomi, H.L.; Suihko, M.L.; Maunuksela, L.; Raaska, L.; Mattila-Sandholm, T. Heterotrophic microorganisms in air and biofilm samples from Roman catacombs, with special emphasis on actinobacteria and fungi. Int. Biodeterior. Biodegrad. 2004, 54, 27-37. [CrossRef]

37. Sterflinger, K. Fungi as geologic agents. Geomicrobiol. J. 2000, 17, 97-124. [CrossRef]

38. Liu, X.B.; Koestler, R.J.; Warscheid, T.; Katayama, Y.; Gu, J.-D. Microbial deterioration and sustainable conservation of stone monuments and buildings. Nat. Sustain. 2020, 1-14. [CrossRef] 
39. Ma, Y.T.; Zhang, H.; Du, Y.; Tian, T.; Xiang, T.; Liu, X.D.; Wu, F.S.; An, L.Z.; Wang, W.F.; Gu, J.-D.; et al. The community distribution of bacteria and fungi on ancient wall paintings of the Mogao Grottoes. Sci. Rep. 2015, 5, 7752. [CrossRef]

40. Liu, X.B.; Meng, H.; Wang, Y.L.; Katayama, Y.; Gu, J.-D. Water is a critical factor in evaluating and assessing microbial colonization and destruction of Angkor sandstone monuments. Int. Biodeterior. Biodegrad. 2018, 133, 9-16. [CrossRef]

41. Saijo, Y.; Nakagi, Y.; Ito, T.; Sugioka, Y.; Endo, H.; Yoshida, T. Relation of Dampness to Sick Building Syndrome in Japanese Public Apartment Houses. Epidemiology 2009, 20, S150. [CrossRef]

42. Polo, A.; Cappitelli, F.; Brusetti, L.; Principi, P.; Villa, F.; Giacomucci, L.; Ranalli, G.; Sorlini, C. Feasibility of Removing Surface Deposits on Stone Using Biological and Chemical Remediation Methods. Microb. Ecol. 2010, 60, 1-14. [CrossRef]

43. Dicus, D.H. One response to a collection-wide mold outbreak: How bad can it be, how good can it get? J. Am. Inst. Conserv. 2000, 39, 85-105. [CrossRef]

44. Diaz-Herraiz, M.; Jurado, V.; Cuezva, S.; Laiz, L.; Pallecchi, P.; Tiano, P.; Sanchez-Moral, S.; Saiz-Jimenez, C. The Actinobacterial Colonization of Etruscan Paintings. Sci. Rep. 2013, 3, 1440. [CrossRef]

45. American Institute for Conservation of Historic and Artistic Works. Strategic Plan; American Institute for Conservation of Historic and Artistic Works: Washington, DC, USA, 1990; 54p.

46. Arai, H. Foxing caused by Fungi: Twenty-five years of study. Int. Biodeterior. Biodegrad. 2000, 46, 181-188. [CrossRef]

47. Choi, S. Foxing on paper: A literature review. J. Am. Inst. Conserv. 2007, 46, 137-152. [CrossRef]

48. Gates, G.A. Discovering the material secrets of art: Tools of cultural heritage science. Am. Ceram. Soc. Bull. 2014, 93, 20-27.

49. Gu, J.-D. Microbiological deterioration and degradation of synthetic polymeric materials: Recent research advances. Int. Biodeterior. Biodegrad. 2003, 52, 69-91. [CrossRef]

50. Duan, Y.L. The microbial community characteristics of ancient painted sculptures in Maijishan Grottoes, China (vol 12, 2017). PLoS ONE 2018, 13, e0179718. [CrossRef]

51. Xu, H.B.; Tsukuda, M.; Takahara, Y.; Sato, T.; Gu, J.-D.; Katayama, Y. Lithoautotrophical oxidation of elemental sulfur by fungi including Fusarium solani isolated from sandstone Angkor temples. Int. Biodeterior. Biodegrad. 2018, 126, 95-102. [CrossRef]

52. Cole, A.C.; Semmens, M.J.; LaPara, T.M. Stratification of activity and bacterial community structure in biofilms grown on membranes transferring oxygen. Appl. Environ. Microb. 2004, 70, 1982-1989. [CrossRef]

53. Fdz-Polanco, F.; Mendez, E.; Uruena, M.A.; Villaverde, S.; Garcia, P.A. Spatial distribution of heterotrophs and nitrifiers in a submerged biofilter for nitrification. Water Res. 2000, 34, 4081-4089. [CrossRef]

54. Stewart, P.S.; Camper, A.K.; Handran, S.D.; Huang, C.T.; Warnecke, M. Spatial distribution and coexistence of Klebsiella pneumoniae and Pseudomonas aeruginosa in biofilms. Microb. Ecol. 1997, 33, 2-10. [CrossRef]

55. McNamara, C.J.; Perry, T.D.; Bearce, K.A.; Hernandez-Duque, G.; Mitchell, R. Epilithic and endolithic bacterial communities in limestone from a Maya archaeological site. Microb. Ecol. 2006, 51, 51-64. [CrossRef]

56. Lan, W.S.; Li, H.; Wang, W.D.; Katayama, Y.; Gu, J.-D. Microbial Community Analysis of Fresh and Old Microbial Biofilms on Bayon Temple Sandstone of Angkor Thom, Cambodia. Microb. Ecol. 2010, 60, $105-115$. [CrossRef] [PubMed]

57. Yamaguchi, N.; Ishidoshiro, A.; Yoshida, Y.; Saika, T.; Senda, S.; Nasu, M. Development of an adhesive sheet for direct counting of bacteria on solid surfaces. J. Microbiol. Methods 2003, 53, 405-410. [CrossRef]

58. Hu, H.L.; van den Brink, J.; Gruben, B.S.; Wosten, H.A.B.; Gu, J.-D.; de Vries, R.P. Improved enzyme production by co-cultivation of Aspergillus niger and Aspergillus oryzae and with other fungi. Int. Biodeterior. Biodegrad. 2011, 65, 248-252. [CrossRef]

59. Hu, H.L.; Ding, S.P.; Katayama, Y.; Kusumi, A.; Li, S.X.; de Vries, R.P.; Wang, J.; Yu, X.Z.; Gu, J.-D. Occurrence of Aspergillus allahabadii on sandstone at Bayon temple, Angkor Thom, Cambodia. Int. Biodeterior. Biodegrad. 2013, 76, 112-117. [CrossRef]

60. Kusumi, A.; Li, X.S.; Katayama, Y. Mycobacteria isolated from Angkor monument sandstones grow chemolithoautotrophically by oxidizing elemental sulfur. Front. Microbiol 2011, 2, 104. [CrossRef] [PubMed]

61. Li, X.S.; Arai, H.; Shimoda, I.; Kuraishi, H.; Katayama, Y. Enumeration of Sulfur-Oxidizing Microorganisms on Deteriorating Stone of the Angkor Monuments, Cambodia. Microbes Environ. 2008, 23, 293-298. [CrossRef] 
62. Li, X.S.; Sato, T.; Ooiwa, Y.; Kusumi, A.; Gu, J.-D.; Katayama, Y. Oxidation of Elemental Sulfur by Fusarium solani Strain THIF01 Harboring Endobacterium Bradyrhizobium sp. Microb. Ecol. 2010, 60, 96-104. [CrossRef]

63. Mitchell, R.; Gu, J.-D. Changes in the biofilm microflora of limestone caused by atmospheric pollutants. Int. Biodeterior. Biodegrad. 2000, 46, 299-303. [CrossRef]

64. Hanada, S.; Hiraishi, A.; Shimada, K.; Matsuura, K. Chloroflexus Aggregans Sp-Nov, a Filamentous Phototrophic Bacterium Which Forms Dense Cell Aggregates by Active Gliding Movement. Int. J. Syst. Bacteriol. 1995, 45, 676-681. [CrossRef]

65. Hanada, S.; Takaichi, S.; Matsuura, K.; Nakamura, K. Roseiflexus castenholzii gen. nov., sp nov., a thermophilic, filamentous, photosynthetic bacterium that lacks chlorosomes. Int. J. Syst. Evolut. Microbiol. 2002, 52, 187-193. [CrossRef]

66. Pierson, B.K.; Giovannoni, S.J.; Stahl, D.A.; Castenholz, R.W. Heliothrix-Oregonensis, Gen-Nov, Sp-Nov, a Phototrophic Filamentous Gliding Bacterium Containing Bacteriochlorophyll-A. Arch. Microbiol. 1985, 142, 164-167. [CrossRef]

67. Nubel, U.; Bateson, M.M.; Madigan, M.T.; Kuhl, M.; Ward, D.M. Diversity and distribution in hypersaline microbial mats of bacteria related to Chloroflexus spp. Appl. Environ. Microb. 2001, 67, 4365-4371. [CrossRef]

68. Sekiguchi, Y.; Yamada, T.; Hanada, S.; Ohashi, A.; Harada, H.; Kamagata, Y. Anaerolinea thermophila gen. nov., sp nov and Caldilinea aerophila gen. nov., sp nov., novel filamentous thermophiles that represent a previously uncultured lineage of the domain Bacteria at the subphylum level. Int. J. Syst. Evolut. Microbiol. 2003, 53, 1843-1851. [CrossRef] [PubMed]

69. Keppen, O.I.; Tourova, T.P.; Kuznetsov, B.B.; Ivanovsky, R.N.; Gorlenko, V.M. Proposal of Oscillochloridaceae fam. nov, on the basis of a phylogenetic analysis of the filamentous anoxygenic phototrophic bacteria, and emended description of Oscillochloris and Oscillochloris trichoides in comparison with further new isolates. Int. J. Syst. Evolut. Microbiol. 2000, 50, 1529-1537. [CrossRef] [PubMed]

70. Warscheid, T.; Braams, J. Biodeterioration of stone: A review. Int. Biodeterior. Biodegrad. 2000, 46, 343-368. [CrossRef]

71. Laiz, L.; Pinar, G.; Lubitz, W.; Saiz-Jimenez, C. Monitoring the colonization of monuments by bacteria: Cultivation versus molecular methods. Environ. Microbiol. 2003, 5, 72-74. [CrossRef] [PubMed]

72. Kaarakainen, P.; Rintala, H.; Vepsalainen, A.; Hyvarinen, A.; Nevalainen, A.; Meklin, T. Microbial content of house dust samples determined with qPCR. Sci. Total Environ. 2009, 407, 4673-4680. [CrossRef] [PubMed]

73. Amann, R.I.; Ludwig, W.; Schleifer, K.H. Phylogenetic Identification and in-Situ Detection of Individual Microbial-Cells without Cultivation. Microbiol. Rev. 1995, 59, 143-169. [CrossRef] [PubMed]

74. Colwell, R.R.; Brayton, P.R.; Grimes, D.J.; Roszak, D.B.; Huq, S.A.; Palmer, L.M. Viable but Non-Culturable Vibrio-Cholerae and Related Pathogens in the Environment-Implications for Release of Genetically Engineered Microorganisms. Nat. Biotechnol. 1985, 3, 817-820. [CrossRef]

75. Rahman, I.; Shahamat, M.; Chowdhury, M.A.R.; Colwell, R.R. Potential virulence of viable but nonculturable Shigella dysenteriae type 1. Appl. Environ. Microb. 1996, 62, 115-120. [CrossRef]

76. Rosado, T.; Mirao, J.; Candeias, A.; Caldeira, A.T. Microbial communities analysis assessed by pyrosequencing-a new approach applied to conservation state studies of mural paintings. Anal. Bioanal. Chem. 2014, 406, 887-895. [CrossRef]

77. Riley, M.; Anilionis, A. Evolution of Bacterial Genome. Annu. Rev. Microbiol. 1978, 32, 519-560. [CrossRef]

78. Otlewska, A.; Adamiak, J.; Gutarowska, B. Application of molecular techniques for the assessment of microorganism diversity on cultural heritage objects. Acta Biochim. Pol. 2014, 61, 217-225. [CrossRef]

79. Adamiak, J.; Otlewska, A.; Tafer, H.; Lopandic, K.; Gutarowska, B.; Sterflinger, K.; Pinar, G. First evaluation of the microbiome of built cultural heritage by using the Ion Torrent next generation sequencing platform. Int. Biodeterior. Biodegrad. 2018, 131, 11-18. [CrossRef]

80. Gutarowska, B.; Celikkol-Aydin, S.; Bonifay, V.; Otlewska, A.; Aydin, E.; Oldham, A.L.; Brauer, J.I.; Duncan, K.E.; Adamiak, J.; Sunner, J.A.; et al. Metabolomic and high-throughput sequencing analysis-modern approach for the assessment of biodeterioration of materials from historic buildings. Front. Microbiol. 2015, 6, 979. [CrossRef] [PubMed]

81. Bartoli, F.; Municchia, A.C.; Futagami, Y.; Kashiwadani, H.; Moon, K.H.; Caneva, G. Biological colonization patterns on the ruins of Angkor temples (Cambodia) in the biodeterioration vs bioprotection debate. Int. Biodeterior. Biodegrad. 2014, 96, 157-165. [CrossRef] 
82. Selbmann, L.; Onofri, S.; Zucconi, L.; Isola, D.; Rottigni, M.; Ghiglione, C.; Piazza, P.; Alvaro, M.C.; Schiaparelli, S. Distributional records of Antarctic fungi based on strains preserved in the Culture Collection of Fungi from Extreme Environments (CCFEE) Mycological Section associated with the Italian National Antarctic Museum (MNA). Mycokeys 2015, 10, 57-71. [CrossRef]

83. Perito, B.; Cavalieri, D. Innovative metagenomic approaches for detection of microbial communities involved in biodeteriorattion of cultural heritage. IOP Conf. Ser. Mater. Sci. Eng. 2018, 364. [CrossRef]

84. Ding, X.H.; Lan, W.S.; Wu, J.P.; Hong, Y.G.; Li, Y.L.; Ge, Q.; Urzi, C.; Katayama, Y.; Gu, J.-D. Microbiome and nitrate removal processes by microorganisms on the ancient Preah Vihear temple of Cambodia revealed by metagenomics and N-15 isotope analyses. Appl. Microbiol. Biotechnol. 2020, 1-15. [CrossRef]

85. Meng, H.; Luo, L.; Chan, H.W.; Katayama, Y.; Gu, J.-D. Higher diversity and abundance of ammonia-oxidizing archaea than bacteria detected at the Bayon Temple of Angkor Thom in Cambodia. Int. Biodeterior. Biodegrad. 2016, 115, 234-243. [CrossRef]

86. de Felice, B.; Pasquale, V.; Tancredi, N.; Scherillo, S.; Guida, M. Genetic fingerprint of microorganisms associated with the deterioration of an historical tuff monument in Italy. J. Genet. 2010, 89, 253-257. [CrossRef] [PubMed]

87. Ettenauer, J.; Pinar, G.; Sterflinger, K.; Gonzalez-Munoz, M.T.; Jroundi, F. Molecular monitoring of the microbial dynamics occurring on historical limestone buildings during and after the in situ application of different bio-consolidation treatments. Sci. Total Environ. 2011, 409, 5337-5352. [CrossRef] [PubMed]

88. Rodriguez, G.G.; Phipps, D.; Ishiguro, K.; Ridgway, H.F. Use of a Fluorescent Redox Probe for Direct Visualization of Actively Respiring Bacteria. Appl. Environ. Microb. 1992, 58, 1801-1808. [CrossRef]

89. Berthold, F.; Tarkkanen, V. Luminometer development in the last four decades: Recollections of two entrepreneurs. Luminescence 2013, 28, 1-6. [CrossRef]

90. Rakotonirainy, M.S.; Arnold, S. Development of a new procedure based on the energy charge measurement using ATP bioluminescence assay for the detection of living mould from graphic documents. Luminescence 2008, 23, 182-186. [CrossRef]

91. Lowenthal, D. The Past is a Foreign Country; Cambridge University Press: Cambridge Cambridgeshire, UK; New York, NY, USA, 1985; p. xxvii. 489p.

92. Zhang, G.X.; Gong, C.J.; Gu, J.G.; Katayama, Y.; Someya, T.; Gu, J.-D. Biochemical reactions and mechanisms involved in the biodeterioration of stone world cultural heritage under the tropical climate conditions. Int. Biodeterior. Biodegrad. 2019, 143, 104723. [CrossRef]

93. Saiz-Jimenez, C.; Laiz, L. Occurrence of halotolerant/halophilic bacterial communities in deteriorated monuments. Int. Biodeterior. Biodegrad. 2000, 46, 319-326. [CrossRef]

94. Jimenez-Lopez, C.; Rodriguez-Navarro, C.; Pinar, G.; Carrillo-Rosua, F.J.; Rodriguez-Gallego, M.; Gonzalez-Munoz, M.T. Consolidation of degraded ornamental porous limestone stone by calcium carbonate precipitation induced by the microbiota inhabiting the stone. Chemosphere 2007, 68, 1929-1936. [CrossRef]

Publisher's Note: MDPI stays neutral with regard to jurisdictional claims in published maps and institutional affiliations.

(C) 2020 by the authors. Licensee MDPI, Basel, Switzerland. This article is an open access article distributed under the terms and conditions of the Creative Commons Attribution (CC BY) license (http://creativecommons.org/licenses/by/4.0/). 